\title{
Focused abdominal ultrasound for blunt trauma in an emergency department without advanced imaging or on-site surgical capability
}

\author{
Michael Shuster, MD; ${ }^{*}$ Riyad B. Abu-Laban, MD, MHSc; ${ }^{\dagger}$ Jeff Boyd, MB BS; ${ }^{*}$ Charles Gauthier, MD; ${ }^{*}$ \\ Sandra Mergler, MD; ${ }^{*}$ Lance Shepherd, MD; ${ }^{*}$ Chris Turner, MD*
}

\begin{abstract}
Objectives: To determine whether focused abdominal sonogram for trauma (FAST) in a rural hospital provides information that prompts immediate transfer to a tertiary care facility for patients with blunt abdominal trauma who would otherwise be discharged or held for observation.

Methods: Prior to the study, participating emergency physicians underwent a minimum of 30 hours of ultrasound training. All patients who presented with blunt abdominal trauma to our rural hospital between Mar. 1, 2002, and Apr. 30, 2003, were eligible for study. Following a history and physical examination, the emergency physician documented his or her disposition decision. A FAST was then performed, and the disposition reconsidered in light of the FAST results. Results: Sixty-seven FAST exams were performed on 65 patients. Three examinations (4.5\%) were true-positive (95\% confidence interval $[\mathrm{Cl}]$ 0.9\%-12.5\%); $60(89.6 \%)$ were true-negative $(95 \% \mathrm{Cl}$ $79.7 \%-95.7 \%), 4(6 \%)$ were false-negative $(95 \% \mathrm{Cl} 1.7 \%-14.6 \%)$ and none $(0 \%)$ were false-positive $(95 \% \mathrm{Cl} 0 \%-5.4 \%)$. These values reflect sensitivity, specificity, negative predictive value and positive predictive values of $43 \%, 100 \%, 94 \%$ and $100 \%$ respectively. FAST results did not alter the decision to transfer any patient (0\%: $95 \% \mathrm{Cl} 0.0 \%-5.4 \%)$, although one positive FAST may have led to an expedited transfer. One of 38 patients who was discharged after a negative FAST study returned 24 hours later because of worsening symptoms, and was ultimately found to have splenic and pancreatic injuries.

Conclusions: This study failed to demonstrate that FAST improves disposition decisions for patients with blunt abdominal trauma who are evaluated in a hospital without advanced imaging or on-site surgical capability. However, the study is not sufficiently powered to rule out a role for FAST in these circumstances, and our data suggest that up to $5.4 \%$ of transfer decisions could be influenced by FAST. Rural emergency physicians should not allow a negative FAST study to override a clinical indication for transfer to a trauma centre; however, positive FAST studies can be used to accelerate transfer for definitive treatment.
\end{abstract}

Key words: ultrasonography, emergency medicine, blunt trauma, abdominal injuries, rural hospitals

RÉSUMÉ

Objectifs : Déterminer si une échographie abdominale ciblée pour l'identification de traumatismes (focused abdominal sonogram for trauma [FAST]) dans un hôpital rural fournit l'information justifiant un transfert immédiat vers un centre de soins tertiaires chez les patients atteints

*Department of Emergency Medicine, Mineral Springs Hospital, Banff, Alta. tDepartment of Emergency Medicine and the Centre for Clinical Epidemiology and Evaluation, Vancouver General Hospital, Division of Emergency Medicine, University of British Columbia, Vancouver, BC

Received: Jan. 8, 2004; final submission: May 11, 2004; accepted: June 5, 2004

This article has been peer reviewed.

Can J Emerg Med 2004;6(6):408-15 
d'un traumatisme abdominal contondant qui seraient normalement renvoyés à la maison ou gardés en observation.

Méthodes : Avant l'étude, les médecins d'urgence participants ont reçu un minimum de 30 heures de formation à l'utilisation de l'échographie. Tous les patients reçus à notre hôpital rural pour un traumatisme abdominal contondant entre le $1^{\text {er }}$ mars 2002 et le 30 avril 2003 étaient admissibles à l'étude. Après l'anamnèse et l'examen physique, le médecin d'urgence nota sa décision quant aux dispositions à prendre. Un examen FAST fut alors effectué et les dispositions furent reconsidérées à la lumière des résultats.

Résultats : Soixante-sept examens FAST furent effectués auprès de 65 patients. Trois examens $(4,5 \%)$ étaient vrais positifs (intervalle de confiance [IC] $95 \%, 0,9 \%-12,5 \%) ; 60(89,6 \%)$ étaient vrais négatifs (IC $95 \%, 79,7 \%-95,7 \%$ ); 4 (6\%) étaient faux négatifs (IC $95 \%, 1,7 \%-14,6 \%$ ) et aucun $(0 \%)$ n'était faux positif (IC $95 \%, 0 \%-5,4 \%$ ). Ces valeurs reflètent une sensibilité à $43 \%$, une spécificité à $100 \%$, une valeur prédictive négative à $94 \%$ et des valeurs prédictives positives à $100 \%$. Les résultats des examens FAST n'ont modifié la décision de transférer aucun patient ( $0 \%$ : IC $95 \%, 0,0 \%-5,4 \%$ ), bien qu'un résultat de FAST positif ait pu mener à un transfert accéléré. Un patient parmi les 38 ayant reçu leur congé après un examen FAST négatif est revenu à l'hôpital au bout de vingt-quatre heures en raison de l'aggravation de ses symptômes. On diagnostiqua des blessures à la rate et au pancréas.

Conclusions : Cette étude n'a pas démontré que l'examen FAST améliorait les décisions quant aux dispositions à prendre pour les patients atteints d'un traumatisme abdominal contondant évalués à un hôpital qui n'est pas doté d'appareils d'imagerie perfectionnés ni de services de chirurgie sur place. Cependant, l'envergue de l'étude n'est pas suffisante pour écarter le rôle de l'examen FAST dans ces circonstances et nos données suggèrent que jusqu'à $5,4 \%$ des décisions de transfert pourraient être influencées par les résultats de l'examen FAST. Les médecins d'urgence en milieu rural ne devraient pas laisser des résultats négatifs d'un examen FAST prendre la priorité sur l'indication clinique de transfert vers un centre de trauma; cependant, on peut recourir à des résultats positifs pour accélérer le transfert du patient vers un traitement définitif.

\section{Introduction}

Despite having fewer resources, emergency physicians in rural hospitals strive to provide blunt trauma patients with care equivalent to that available in urban centres. Rural hospitals rarely have advanced imaging modalities such as CT scan or emergency ultrasound. As a result, emergency physicians in such centres are forced to rely on clinical examination and plain radiography alone. Lack of advanced imaging may delay the identification of patients who require transfer, or lead to inappropriate transfer of patients who are later found not to require trauma centre intervention.

Emergency department (ED) ultrasound in blunt trauma, also known as FAST (focused abdominal sonogram in trauma), is highly sensitive and specific for the detection of free intraperitoneal fluid. FAST may detect free fluid in the setting of blunt trauma prior to development of definitive clinical findings, potentially enabling more accurate decision-making and earlier transfer when indicated. Numerous studies have been published in the past 10 years demonstrating the utility of FAST. These studies have addressed who should perform FAST, ${ }^{1-7}$ how much training is required to perform these limited exams, ${ }^{7-12}$ which patients benefit ${ }^{13-22}$ and how they benefit. ${ }^{21,23}$ No previous study has examined the application of FAST in an ED without advanced imaging or on-site surgical capability.

The primary objective of this study was to evaluate whether a single FAST examination at patient presentation, when performed by rural emergency physicians, prompts the immediate transfer of patients who would otherwise have been observed or discharged, and who are later proven to have free intraperitoneal fluid.

\section{Methods}

\section{Setting}

This prospective study was conducted at Mineral Springs Hospital, a rural community hospital that treats $15000 \mathrm{ED}$ patients annually and is staffed by full-time certified emergency physicians. The hospital is located in Banff, Alta., a mountain community of 7600, inside a National Park and adjacent to the Trans-Canada Highway.

\section{Study procedures}

Participating emergency physicians undertook a minimum of 30 hours of training in the ultrasound department of a university teaching hospital trauma centre, under the supervision of certified radiologists. They performed FAST ex- 
ams on elective ultrasound patients and on trauma patients who presented during their training period. On completion of training, all physicians were comfortable in their ability to perform and interpret a FAST, but their skills were not formally evaluated.

From Mar. 1, 2002, to Apr. 30, 2003, patients who presented after abdominal trauma with a potential to cause serious injury, as determined by the attending emergency physician, were eligible for inclusion. Emergency physicians performed a history and physical exam, then decided, based on clinical considerations, which of the following dispositions was appropriate: transfer to a tertiary care facility, observation in the ED, admission to our rural hospital, or discharge. After the clinical disposition decision was documented on a study form kept on the ED ultrasound machine, a FAST was performed. The disposition was then reconsidered in light of the FAST results (free fluid v. no free fluid). Aside from the FAST, no change in standard diagnostic or therapeutic care occurred as a result of this study. Patients who were unstable, or those who were stable but deemed to require urgent transfer to a tertiary care facility were enrolled only if the FAST did not interfere with care and did not delay transfer.

\section{Safety and consent}

To assure patient safety in the event of false-negative FAST results, the study protocol stipulated that actual disposition could only be "upgraded" as a result of a FAST; thus FAST was used in a "rule in" rather than a "rule out" manner. No patient deemed on clinical grounds to require transfer could have this decision changed on the basis of a negative FAST. Written informed consent was obtained whenever possible, verbal consent when patients were unable to sign, and proxy consent when neither written nor verbal consent was possible. The study was approved by the Provincial Research Ethics Board and the Mineral Springs Hospital Medical Advisory Committee.

\section{Follow-up}

The attending physician, nurse or principal investigator (M.S.) conducted a telephone interview 24 hours or more after discharge, with all patients who were discharged from the ED without first undergoing definitive testing (i.e., formal ultrasound, CT scan or surgery). These patients were asked whether they had seen another physician or received additional testing since their discharge from the ED. Results of any physician visit or additional testing were reviewed, and relevant data were recorded. For patients who were transferred to a tertiary referral centre, pertinent imaging results, diagnoses and outcomes were obtained from the receiving hospital and documented in the study database.

\section{Data analysis}

Data were entered into Microsoft Excel 2000 (Version 2002). Descriptive statistics, including proportions, means, standard deviations and medians were calculated, using Excel. Binomial 95\% confidence intervals (CIs) for proportions were calculated using Stata (Version 5.0 Macintosh).

\section{Results}

During the study period, 67 FAST exams were performed on 65 patients. Participating physicians performed an average of 11 exams each (range 4-19). One patient was scheduled for, and received, a repeat FAST examination 24 hours after his initial visit because he refused ED observation or transfer for CT or ultrasound at his first visit. A second patient had a repeat FAST approximately 24 hours after discharge when he returned to the ED as instructed because his symptoms were worsening.

Table 1 outlines the characteristics of the study population, and Table 2 summarizes the results of the FAST examination and definitive testing. Thirty-eight (58\%) patients had no definitive test performed and received a follow-up telephone interview. No patients were lost to follow-up. Table 3 shows that no patients had a change of disposition based on the FAST exam.

Table 2 shows that the true prevalence of intra-abdominal pathology was $10.5 \%$. In the study group, 3 FAST examinations $(4.5 \%)$ were true-positive $(95 \%$ CI $0.9 \%-$ $12.5 \%)$; 60 (89\%) were true-negative (95\% CI $79.7 \%$ 95.7\%), 4 (6\%) were false-negative (95\% CI 1.7\%-14.6\%) and none were false-positive (95\% CI 0\%-5.4\%). These values reflect sensitivity, specificity, negative predictive value and positive predictive value of $43 \%, 100 \%, 94 \%$ and $100 \%$ respectively.

Table 4 summarizes key findings and outcomes for the 6 patients with intra-abdominal injuries. Of note, 1 of the 3 patients (patient P1) who had a positive FAST examination had been triaged as Non Urgent. After physical examination he was slated for non-urgent transfer for CT scan, possibly by private vehicle. Although it did not change disposition, the positive FAST examination may have prompted expedited transfer by ambulance. One of 38 patients who was discharged after a negative FAST study (patient P2) returned 24 hours later because of worsening symptoms. Results of the repeat FAST were positive, and he was ultimately found to have splenic and pancreatic injuries. 


\section{Discussion}

FAST has become a routine component of urban trauma care. ${ }^{19,20,2428}$ When the FAST is positive in an unstable patient, it reduces delays to laparotomy by eliminating the need for time-consuming and invasive evaluations like CT scanning or diagnostic peritoneal lavage. In stable patients where suspicion of intra-abdominal hemorrhage is low, observation and serial FAST exams eliminate the need for immediate advanced imaging. If the patient deteriorates or a repeat FAST exam is positive, rapid CT or formal ultrasound can be performed; and if the patient becomes unstable, immediate surgery is available ${ }^{29-37}$ Our study is the first to evaluate the utility of FAST in a hospital where advanced imaging and on-site surgical intervention are not available.

\section{FAST utility in rural settings}

Emergency CT or ultrasound are rarely available in rural hospitals and are often not available in small urban hospitals. Likewise, surgical consultation is often absent or limited in such settings. Emergency physicians practising in these facilities use clinical judgement to determine which patients with blunt abdominal injury can be discharged, which need to be observed or referred for delayed imaging,

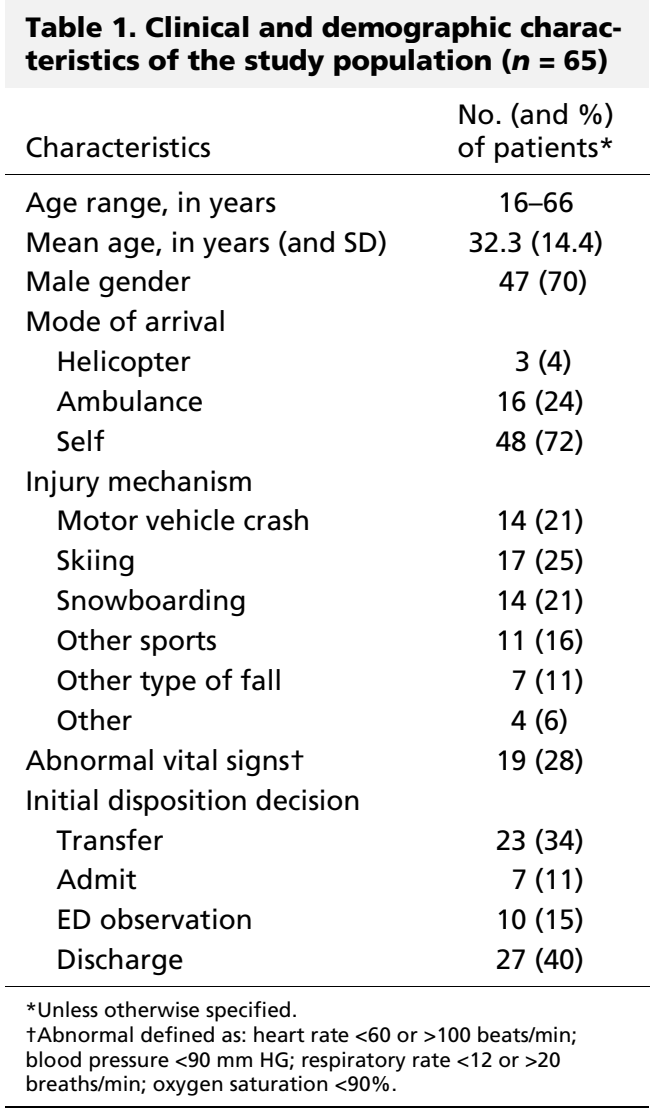

and which, due to instability or symptom severity, require immediate imaging or surgical intervention. Of these various patient groups, only unstable patients are easily identifiable. In unstable patients, the FAST ability to identify free fluid in the abdomen does not influence initial care, because these patients must be urgently transferred regardless of whether free fluid is present. Nonetheless, the detection of free intraperitoneal fluid prior to transfer may provide the receiving facility with important information, particularly if the trauma centre has to reserve an operating room (OR) or call in an OR team.

In hospitals without emergency CT or ultrasound, the more difficult decisions involve patients who have stable vital signs and non-specific physical findings, but who are deemed to have sustained sufficient trauma to cause significant injury. Options for disposition include immediate transfer for imaging, admission and observation with or without delayed imaging, and ED observation with eventual admission, transfer or discharge based on clinical evolution. If FAST could help physicians discriminate stable patients who can be observed from stable patients who re-

\begin{tabular}{|c|c|c|c|}
\hline ED FAST exam & $\begin{array}{l}\text { Definitive test* } \\
\text { positive }\end{array}$ & $\begin{array}{c}\text { Definitive test* } \\
\text { negative }\end{array}$ & Total \\
\hline Positive & 3 & 0 & 3 \\
\hline Negative & 4 & 60 & 64 \\
\hline Total & 7 & 60 & 67 \\
\hline \multicolumn{4}{|c|}{$\begin{array}{l}\text { FAST }=\text { focused abdominal sonogram for trauma } \\
* 38 \text { patients had no definitive test performed. } \\
\text { tOr patient well with no additional imaging, new diagnoses or adverse } \\
\text { outcomes at follow-up. } \\
\text { Prevalence: } 7 / 67(11.0 \%) \text {; Sensitivity: } 3 / 7=43.0 \%(95 \% \text { confidence interval }[\mathrm{Cl}] \\
10.0 \%-82.0 \%) ; \text { Specificity: } 60 / 60=100.0 \%(95 \% \mathrm{Cl} 94.0 \%-100.0 \%) ; \text { Positive } \\
\text { predictive value: } 3 / 3=100.0 \%(95 \% \mathrm{Cl} 29.2 \%-100.0 \%) ; \text { Negative predictive } \\
\text { value: } 60 / 64=93.8 \%(95 \% \mathrm{Cl} 84.8 \%-98.3 \%) .\end{array}$} \\
\hline
\end{tabular}

Table 3. Disposition of the 65 study patients, before and after FAST examination

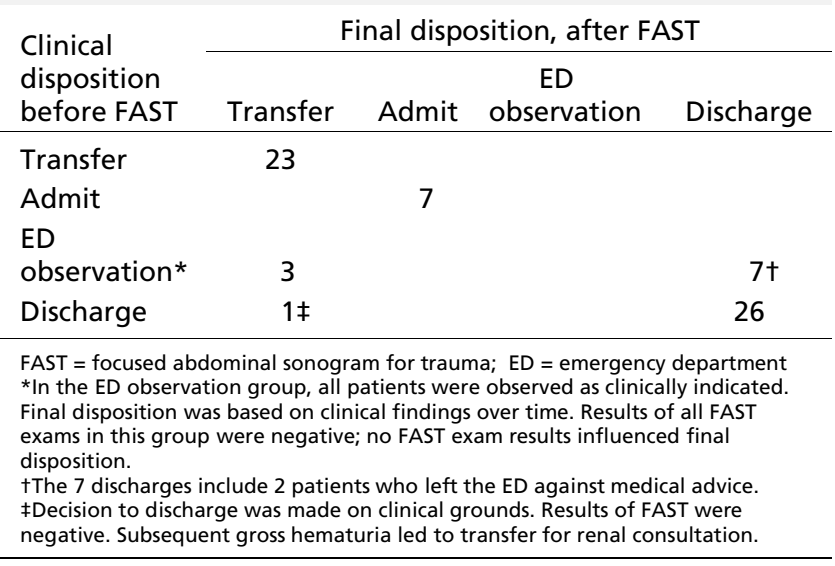


quire prompt transfer for surgical assessment, it would be a very useful modality in the rural ED.

\section{Impact of FAST on disposition}

In this study, FAST had no clear effect on the disposition of patients with blunt trauma. In all 3 cases where the FAST exam was positive, the emergency physician had already made a decision to transfer the patient - although, in one case the positive FAST may have expedited transfer. Moreover, in the "grey zone" population with an initial clinical disposition of admit, observe or discharge, the prevalence of positive FAST was $0 \%$ (0 of 44 patients). This low prevalence of positive FAST in our study population illustrates the difficulty of proving a benefit of FAST for hospitals without advanced imaging or on-site surgical capability. If, for example, a study is carried out in an ED where $5 \%$ of trauma patients have a positive FAST, and if $90 \%$ of these cases require immediate transfer on clinical grounds, then 13912 patients would be required to evaluate the hypothesis that $10 \%$ of positive FAST scans would influence the disposition decision (this sample size calculation assumes $100 \%$ sensitivity, an alpha of $5 \%$ and power of $80 \%$ ). This means that the results of the current study are clearly inconclusive, and that it is unlikely a definitive rural study will ever be done (due to the sample size requirement).

Of the 23 patients who were initially determined to require transfer, 21 had a negative FAST. For safety reasons,

Table 4. Summary of key findings and outcomes for the 6 study participants for whom intraperitoneal free fluid was discovered as a result of definitive testing (CT or US)

\begin{tabular}{|c|c|c|c|c|c|c|c|c|}
\hline Patient & $\begin{array}{l}\text { Age } \\
\text { / Sex }\end{array}$ & $\begin{array}{c}\text { Mechanism } \\
\text { of injury }\end{array}$ & $\begin{array}{c}\text { Time } \\
\text { from } \\
\text { injury } \\
\text { to ED } \\
\text { arrival } \\
\text { (hrs) }\end{array}$ & $\begin{array}{l}\text { Vital signs } \\
\text { on } \\
\text { admission }\end{array}$ & $\begin{array}{c}\text { Initial } \\
\text { disposition }\end{array}$ & $\begin{array}{l}\text { Time } \\
\text { from } \\
\text { FAST } \\
\text { to CT } \\
\text { or US } \\
\text { (hrs) }\end{array}$ & Diagnosis & $\begin{array}{l}\text { Intervention } \\
\text { and outcome }\end{array}$ \\
\hline \multicolumn{9}{|c|}{ FAST positive } \\
\hline P1 & $\begin{array}{l}18 / \\
M\end{array}$ & $\begin{array}{l}\text { Snow- } \\
\text { boarding }\end{array}$ & 1.25 & Normal & Transfer & 2.75 & $\begin{array}{l}\text { Renal, adrenal and } \\
\text { liver lacerations }\end{array}$ & $\begin{array}{l}\text { No intervention. } \\
\text { Uncomplicated } \\
\text { recovery. }\end{array}$ \\
\hline $\begin{array}{l}\text { P2 (2nd } \\
\text { visit)* }\end{array}$ & $\begin{array}{l}19 / \\
M\end{array}$ & $\begin{array}{l}\text { Snow- } \\
\text { boarding }\end{array}$ & 26.5 & Normal & Transfer & 2 & $\begin{array}{l}\text { Pancreatic and splenic } \\
\text { injuries }\end{array}$ & $\begin{array}{l}\text { Splenectomy and } \\
\text { partial pancrea- } \\
\text { tectomy. Uncom- } \\
\text { plicated recovery. }\end{array}$ \\
\hline P3 & $\begin{array}{l}19 / \\
M\end{array}$ & $\begin{array}{l}\text { Snow- } \\
\text { boarding }\end{array}$ & 2 & Normal & Transfer & 3.5 & $\begin{array}{l}\text { Grade } 3-4 \text { splenic } \\
\text { laceration }\end{array}$ & $\begin{array}{l}\text { No intervention. } \\
\text { Uncomplicated } \\
\text { recovery. }\end{array}$ \\
\hline \multicolumn{9}{|c|}{ FAST negative } \\
\hline P4 & $\begin{array}{l}39 / \\
F\end{array}$ & $\begin{array}{l}\text { Motor } \\
\text { vehicle } \\
\text { collision }\end{array}$ & 1 & $\begin{array}{l}\text { HR } 130 \\
\text { beats/min, } \\
\text { BP not } \\
\text { palpable }\end{array}$ & Transfer & 1.5 & $\begin{array}{l}\text { Multiple injuries } \\
\text { including severe head } \\
\text { injury, fractured } \\
\text { mandible, fractured } \\
\text { femur, bilateral } \\
\text { pneumothorax. On CT } \\
\text { had large retroperi- } \\
\text { toneal hematoma and } \\
\text { free intraperitoneal } \\
\text { fluid. }\end{array}$ & $\begin{array}{l}\text { Surgical explora- } \\
\text { tion of abdomen: } \\
\text { no intra-abdom- } \\
\text { inal injuries } \\
\text { indentified. } \\
\text { Coagulopathy. } \\
\text { Died. }\end{array}$ \\
\hline P5 & $\begin{array}{l}19 / \\
M\end{array}$ & $\begin{array}{l}\text { Snow- } \\
\text { boarding }\end{array}$ & 1.5 & $\begin{array}{l}\text { HR } 49 \\
\text { beats/min }\end{array}$ & $\begin{array}{l}\text { ED } \\
\text { observet }\end{array}$ & 0.75 & Splenic laceration & $\begin{array}{l}\text { No intervention. } \\
\text { Uncomplicated } \\
\text { recovery. }\end{array}$ \\
\hline P6 & $\begin{array}{l}18 / \\
M\end{array}$ & $\begin{array}{l}\text { Checked } \\
\text { into boards } \\
\text { playing } \\
\text { hockey }\end{array}$ & 2.75 & Normal & Admit $\ddagger$ & 10 & Splenic laceration & $\begin{array}{l}\text { No intervention. } \\
\text { Uncomplicated } \\
\text { recovery. }\end{array}$ \\
\hline $\begin{array}{l}\text { P2 (1st } \\
\text { visit) }\end{array}$ & $\begin{array}{l}19 / \\
M\end{array}$ & $\begin{array}{l}\text { Snow- } \\
\text { boarding }\end{array}$ & 1.5 & Normal & Discharge & 27 & See P2 (2nd visit) & \\
\hline
\end{tabular}

$\mathrm{CT}=$ computed tomography; US = ultrasound; $\mathrm{FAST}=$ focused abdominal sonogram for trauma; $\mathrm{HR}=$ heart rate; $\mathrm{BP}=$ blood pressure

*Discharged after initial visit (see final row).

†Although the initial decision was to observe patient 5 , the patient was transferred after it became possible to arrange an ultrasound at a nearby rural hospital. ¥Patient 6 was admitted, and a formal ultrasound was scheduled for, and performed at a nearby rural hospital on the day following admission. 
we did not allow a negative FAST exam to downgrade a disposition decision. Some of these patients who had a negative FAST had unstable vital signs, multiple injuries or other injury requiring $\mathrm{CT}$ scan and would have required transfer in any case. Had we used the FAST result to reverse the decision to transfer the remainder of the stable patients, we could have reduced the number of patients we transferred by perhaps $50 \%$ - but not without risk of missing a significant injury. Although none of the stable patients we transferred subsequently had a catastrophic bleed, our sample size is not sufficient to exclude an adverse event as a possibility.

\section{Diagnostic performance of FAST}

In this study, ED FAST exams were $43 \%$ sensitive and $100 \%$ specific. This sensitivity value is lower than values typically reported in the trauma literature, but readers should keep the following points in mind. First, the number of patients with significant injuries is too small for us to estimate test sensitivity with adequate precision. Second, previous authors have shown that an initial FAST can be negative because it takes time for an amount of blood detectable by ultrasound (approximately $250 \mathrm{~mL}$ ) to accumulate in the peritoneal cavity. ${ }^{2,37-40}$ Because of the prolonged delays inherent in transferring patients for definitive testing, a first exam might be accurately negative but a second exam positive. In the 4 false-negative FAST studies, the mean (median) delay from FAST to definitive imaging was 9.3 (5.75) hours. It is impossible to know whether the initial negative FAST study failed to demonstrate free fluid that was present, or whether the free fluid developed during the prolonged time interval between studies; nevertheless, our findings reinforce the concept that a single early FAST study does not rule out intraperitoneal bleeding.

\section{Potential errors}

In this study there were 2 cases of splenic laceration in which inappropriate application of a negative FAST exam could have had a disastrous consequence. In one case the physician made the decision to admit and send the patient for ultrasound the next day; in the second case the physician arranged for transfer for ultrasound that afternoon. In both cases the initial FAST was negative, and in the first case a repeated FAST was also negative. If the physicians had used FAST results to override clinical judgement, the intra-abdominal bleeding would have been missed. These cases emphasize the importance of applying FAST to "rule in" but not to "rule out" significant injury.

\section{Limitations}

Ultrasound is an operator-dependent skill. Individual study physicians may have different levels of expertise, and their expertise may differ from other rural emergency physicians who apply FAST. One of the participating physicians performed only 4 FAST studies during the 1-year study period. There are no data to indicate how many exams are needed in order to maintain ultrasound skills.

These data reflect the diagnostic sensitivity of a single early FAST study rather than the sensitivity of repeated FAST examinations - a more sensitive strategy for defining the need for advanced imaging or surgical intervention. This study does not address the question of whether it is safe to use a negative FAST result and then repeated FAST examinations to determine the need for transfer. Because of the potential for harm and in the absence of proof that holding patients for serial FAST is safe, a negative FAST exam should not be used to reverse a decision to transfer.

Our inclusion criterion, "blunt abdominal trauma with the potential to cause serious injury," is subjective and difficult to reproduce; nevertheless, it reflects the clinical reality that there are no objective parameters to determine which patients require investigation. Thresholds for discharge, admission and transfer vary between physicians; therefore, the likelihood that FAST will influence disposition decisions will also vary between physicians. It is also possible that a Hawthorne effect prompted physicians to enrol patients they would normally not have considered for a FAST, thus skewing our proportion of positive FAST studies downward and potentially reducing the proportion of FAST examinations that had an effect on decision to transfer. In fact, we found no evidence that physicians modified their practice during the study period, and the transfer rate was unchanged compared with the same period in the previous year, but the subjectivity inherent in determining which patients to include in the study and the differing thresholds for disposition could limit the external validity of our findings.

\section{Conclusion}

This study failed to demonstrate that the use of FAST improves disposition decisions for patients with blunt abdominal trauma evaluated in a hospital that does not have advanced imaging or on-site surgical capability. However, the study is not sufficiently powered to rule out a role for FAST in these circumstances, and our data suggest that up to $5.4 \%$ of transfer decisions could be influenced by FAST. Rural emergency physicians should not allow a negative FAST study to override a clinical indication for transfer; 
however, positive FAST studies can be used to accelerate transfer for definitive treatment.

Competing interests: None declared.

Contributors: Dr. Shuster proposed the study. All authors contributed to the study design. Drs. Shuster, Boyd, Gauthier, Mergler, Shepherd and Turner collected the data. Drs. Shuster and Abu-Laban interpreted the data, and Dr. Abu-Laban performed the statistical analysis. Dr. Shuster wrote the initial draft of the manuscript, and Drs. Shuster and Abu-Laban participated in revising the manuscript.

Acknowledgements: We thank Richard Boothroyd, Boothroyd Imaging Solutions Inc., Georgetown, Ont., and Esaote Pie Medical, Maastricht, the Netherlands, for their generous assistance with our emergency department ultrasound program and for the loan of the Falco 100 and Parus ultrasound machines used in this study. We also thank the Mineral Springs Hospital emergency nursing staff, without whose assistance this study would not have been possible.

Support: Dr. Riyad B. Abu-Laban is supported by a Clinical Scholar Award from the Michael Smith Foundation for Health Research.

\section{References}

1. Foo E, Su JW, Menon D, Tan D, Chan ST. A prospective evaluation of surgeon performed sonography as a screening test in blunt abdominal trauma. Ann Acad Med Singapore 2001;30(1):11-4.

2. Frezza EE, Solis RL, Silich RJ, Spence RK, Martin M. Competency-based instruction to improve the surgical resident technique and accuracy of the trauma ultrasound. Am Surg 1999;65 (9):884-8.

3. Ingeman JE, Plewa MC, Okasinski RE, King RW, Knotts FB. Emergency physician use of ultrasonography in blunt abdominal trauma. Acad Emerg Med 1996;3(10):931-7.

4. Kern SJ, Smith RS, Fry WR, Helmer SD, Reed JA, Chang FC. Sonographic examination of abdominal trauma by senior surgical residents. Am Surg 1997;63(8):669-74.

5. Ma OJ, Mateer JR, Ogata M, Kefer MP, Wittmann D, Aprahamian C. Prospective analysis of a rapid trauma ultrasound examination performed by emergency physicians. J Trauma 1995; 38(6):879-85.

6. Mandavia DP, Aragona J, Chan L, Chan D, Henderson SO. Ultrasound training for emergency physicians - a prospective study. Acad Emerg Med 2000;7(9):1008-14.

7. Smith RS, Kern SJ, Fry WR, Helmer SD. Institutional learning curve of surgeon-performed trauma ultrasound. Arch Surg 1998; 133(5):530-5; discussion 535-6.

8. Lanoix R, Baker WE, Mele JM, Dharmarajan L. Evaluation of an instructional model for emergency ultrasonography. Acad Emerg Med 1998;5(1):58-63.

9. McCarter FD, Luchette FA, Molloy M, Hurst JM, Davis K Jr, Johannigman JA. Institutional and individual learning curves for focused abdominal ultrasound for trauma: cumulative sum analysis. Ann Surg 2000;231(5):689-700.
10. Salen P, O'Connor R, Passarello B, Pancu D, Melanson S, Arcona $\mathrm{S}$, et al. Fast education: a comparison of teaching models for trauma sonography. J Emerg Med 2001;20(4):421-5.

11. Shackford SR, Rogers FB, Osler TM, Trabulsy ME, Clauss DW, Vane DW. Focused abdominal sonogram for trauma: the learning curve of nonradiologist clinicians in detecting hemoperitoneum. J Trauma 1999;46(4):553-62; discussion 562-4.

12. Thomas B, Falcone RE, Vasquez D, Pancu D, Melanson S, Arcona $\mathrm{S}$, et al. Ultrasound evaluation of blunt abdominal trauma: program implementation, initial experience, and learning curve. J Trauma 1997;42(3):384-8; discussion 388-90.

13. Ballard RB, Rozycki GS, Newman PG, Cubillos JE, Salomone JP, Ingram WL, et al. An algorithm to reduce the incidence of false-negative FAST examinations in patients at high risk for occult injury. Focused Assessment for the Sonographic Examination of the Trauma Patient. J Am Coll Surg 1999;189(2):145-50; discussion 150-1.

14. Chiu WC, Cushing BM, Rodriguez A, Ho SM, Mirvis SE Shanmuganathan K, et al. Abdominal injuries without hemoperitoneum: a potential limitation of focused abdominal sonography for trauma (FAST). J Trauma 1997;42(4):617-23.

15. Coley BD, Mutabagani KH, Martin LC, Zumberge N, Cooney DR, Caniano DA, et al. Focused abdominal sonography for trauma (FAST) in children with blunt abdominal trauma. J Trauma 2000;48(5):902-6.

16. Corbett SW, Andrews HG, Baker EM, Jones WG. ED evaluation of the pediatric trauma patient by ultrasonography. Am J Emerg Med 2000;18(3):244-9.

17. Kirkpatrick AW, Simons RK, Brown DR, Ng AK, Nicolaou S. Digital hand-held sonography utilised for the focused assessment with sonography for trauma: a pilot study. Ann Acad Med Singapore 2001;30(6):577-81.

18. McGahan JP, Rose J, Coates TL, Wisner DH, Newberry P. Use of ultrasonography in the patient with acute abdominal trauma. $\mathrm{J}$ Ultrasound Med 1997;16(10):653-62.

19. McKenney MG, Martin L, Lentz K, Lopez C, Sleeman D, Aristide $\mathrm{G}$, et al. 1,000 consecutive ultrasounds for blunt abdominal trauma. J Trauma 1996;40(4):607-10, discussion 611-2.

20. Mateer JR, Jehle D. Ultrasonography in emergency medicine. Acad Emerg Med 1994;1(2):149-52.

21. Rozycki GS, Ballard RB, Feliciano DV, Schmidt JA, Pennington SD. Surgeon-performed ultrasound for the assessment of truncal injuries: lessons learned from 1540 patients. Ann Surg 1998;228(4):557-67.

22. Yeo A, Wong CY, Soo KC. Focused abdominal sonography for trauma (FAST). Ann Acad Med Singapore 1999;28(6):805-9.

23. Laviolette E. Need for bedside emergency department ultrasonography: case report of a ruptured ectopic pregnancy. Can J Emerg Med 2004;6(2):112-5.

24. Cardenas E. Limited bedside ultrasound imaging by emergency medicine physicians. West J Med 1998;168(3):188-9. 
25. Heller M. Emergency ultrasound: out of the acoustic shadows. Ann Emerg Med 1997;29(3):380-2.

26. Plummer D. Diagnostic ultrasonography in the emergency department. Ann Emerg Med 1993;22(3):592-4.

27. Simon BC, Snoey ER. Ultrasound in emergency and ambulatory medicine. St. Louis (MO): Mosby; 1997.

28. Witting MD, Euerle BD, Butler KH. A comparison of emergency medicine ultrasound training with guidelines of the Society for Academic Emergency Medicine. Ann Emerg Med 1999; 34(5):604-9.

29. Bode PJ, Edwards MJ, Kruit MC, van Vugt AB. Sonography in a clinical algorithm for early evaluation of 1671 patients with blunt abdominal trauma. Am J Roentgenol 1999;172(4):905-11.

30. Boulanger BR, McLellan BA, Brenneman FD, Ochoa J, Kirkpatrick AW. Prospective evidence of the superiority of a sonography-based algorithm in the assessment of blunt abdominal injury. J Trauma 1999;47(4):632-7.

31. Branney SW, Moore EE, Cantrill SV, Burch JM, Terry SJ. Ultrasound based key clinical pathway reduces the use of hospital resources for the evaluation of blunt abdominal trauma. $\mathbf{J}$ Trauma 1997;42(6):1086-90.

32. Godwin SA. Introduction to emergency ultrasound: a review of justifications, indications and significant findings. Jacksonville Med 1999;50(3).

33. Holm C, Larsen MS, Houshian S, Torfing T. [Ultrasonographic scanning of patients with severe abdominal injuries.] Ugeskr Laeger 2001;163(43):5967-70.

34. Ng A. Trauma ultrasonography: the FAST and beyond. Available: www.trauma.org/radiology/FASTintro.html (accessed 2004 Aug 30).

35. Patel JC, Tepas JJ 3rd. The efficacy of focused abdominal sonography for trauma (FAST) as a screening tool in the assessment of injured children. J Pediatr Surg 1999;34(1):44-7.

36. Rozycki GS, Shackford SR. Ultrasound, what every trauma surgeon should know. J Trauma 1996;40(1):1-4.

37. Tiling T, Bouillon B, Schmid A. Ultrasound in blunt abdominothoracic trauma. New York (NY): Marcel Dekker; 1990.

38. Jehle D, Davis E, Evans T, Harchelroad F, Martin M, Zaiser K, et al. Emergency department sonography by emergency physicians. Am J Emerg Med 1989;7(6):605-11.

39. Kawaguchi S, Toyonaga J, Ikeda K. Five point method: an ultrasonographic quantification formula of intra-abdominal fluid collection. Japan J Acute Med 1987;7:993-7.

40. Von Kuenssberg Jehle D, Stiller G, Wagner D. Sensitivity in detecting free intraperitoneal fluid with the pelvic views of the FAST exam. Am J Emerg Med 2003;21(6):476-8.

Correspondence to: Dr. Michael Shuster, Mineral Springs Hospital, Box 1050, Banff AB T1L 1H7; shuster@telus.net 